\title{
EFFECTIVENESS OF TEETH BLEACHING (38\% HYDROGEN PEROXIDE) AFTER THE APPLICATION OF 10\% SODIUM ASCORBATE AS AN ANTIOXIDANT
}

\author{
José Macario Hernandez Izaguirre ${ }^{1}$, Mario Alberto Palomares Rodríguez ${ }^{1}$, \\ María Teresa Ley Fong ${ }^{1}$, Francisco Javier Llamas Del Olmo ${ }^{1}$, \\ Carlos Alberto Luna Lara ${ }^{1}$, Claudia Penélope Mora López ${ }^{1}$
}

${ }^{1}$ Professor of the Dentistry Faculty, Autonomous University of Tamaulipas.

DOI: 10.46609/IJETSI.2020.v05i01.005 URL: https://doi.org/10.46609/IJETSI.2020.v05i01.005

\section{ABSTRACT}

Teeth whitening plays an important role in the acceptance of patients for cosmetic dental treatments. When tooth whitening is unfavorable, adhesive resins are used, however, these are diminished by residual oxygen, which is eliminated with antioxidant substances after bleaching. The purpose is to assess the effectiveness of teeth whitening after placement of $10 \%$ sodium ascorbate. Materials and methods: It was an experimental, in vitro and comparative study of two groups of 11 premolar samples each; with longitudinal measurement of the effectiveness of hydrogen peroxide $(38 \%)$ after the application of sodium ascorbate (10\%), subjecting it to a color check using the Vita®Easy Shade spectrophotometer based on the Vitapan Classical® colorimeter measurement scale. The statistical program IBM SPSS STATICS 23 was used. Results: It was observed that the use of $38 \%$ hydrogen peroxide bleaching after the application of an antioxidant such as $10 \%$ sodium ascorbate does not present statistically significant changes, which indicates that indeed the use of an antioxidant after bleaching It does not affect its effectiveness. Conclusion: $10 \%$ sodium ascorbate does not affect the effectiveness of $38 \%$ hydrogen peroxide bleaching in any of the time periods evaluated in the present study.

Keywords: teeth whitening, sodium ascorbate, antioxidant.

\section{INTRODUCTION}

Vital teeth whitening is one of the most performed procedures in dentistry, due to its simplicity and the high demand for cosmetic treatments; in dentistry in teeth with pigmentation problems. The strength of adhesion to the enamel of a composite resin is modified by the bleaching agents, that is, by the interaction with the residual oxygen in the form of free radicals that is maintained 


\section{International Journal of Engineering Technology and Scientific Innovation}

ISSN: 2456-1851

Volume: 05, Issue: 01 "January-February 2020"

in the adamantine prisms and dentinal tubes two to four weeks later once the bleaching is finished, inhibiting the adhesive capacity (1). There are several approaches to teeth whitening, which have been adopted by dental specialists and are the following:

A) Outpatient whitening: consisting of topical application of carbamide peroxide or hydrogen peroxide in low concentrations and personally applied by the patient who wants to undergo such treatment.

B) Whitening in the office is a faster procedure, in which the application of carbamide peroxide or hydrogen peroxide is carried out at higher concentrations, applied by a specialist and under clinical control, to evaluate the evolution of the patient with respect to the treatment (2).

The classification and composition of bleaching agents mostly used for such treatment; and both agree that those of greater demand and use are the bleaching agents based on hydrogen peroxide and carbamide; which are presented in various concentrations, the largest ranging from 30 to $50 \%$ are for exclusive use of office whitening, and presentations for outpatient whitening that is in the patient's home, range from 5.5 to $7.5 \%$ for peroxide hydrogen and 10 to $22 \%$ for carbamide peroxide (3-4).

Despite the success of the Marshall (5) et al treatment, they warn that bleaching agents contain unstable peroxides that produce oxygen free radicals that are highly unstable, which break up the major and intensely pigmented organic carbon ring compounds that contain the enamel matrix, and thus convert the shorter and less pigmented chain molecules, this process is known as oxidation. If this is maintained for a long time, it overcomes the bleaching phase, being able to break down the organic materials into carbon dioxide and water, which represents the loss of enamel matrix. After tooth whitening, the presence of oxygen on the dental surface is eliminated until after two weeks after the application of the bleaching peroxides; the use of certain antioxidants can reduce this time to only a few minutes.

Haywood (3) comments that oxidation is the mechanism through which the effects of bleaching are achieved. Any oxidizing agent is characterized by presenting an unpaired electron in its external orbit; therefore, it has a strong tendency to interact with other electrons, this in order to generate a pair of electrons and achieve stability.

In search of treatments to prevent this oxidation process that occurs at the time of applying a teeth whitening treatment Martin (6) et al determined that an antioxidant is a molecule capable of retarding or preventing that oxidation process of other molecules, since this It is a chemical reaction of electron transfer from a substance to an oxidizing agent. 


\section{International Journal of Engineering Technology and Scientific Innovation}

ISSN: 2456-1851

Volume: 05, Issue: 01 "January-February 2020"

Zamora (7) mentions that an antioxidant with biological function is defined as that substance that, if present in small concentrations, decreases or prevents oxidation of the substrate. In biochemistry, it can be considered as an electron donor capable of avoiding an oxide-reduction chain reaction.

Nieto Alcaide and Martínez Vázquez (8) classify antioxidants into two types according to the mechanism of action, these are:

A) Preventive antioxidants: these act at the beginning of an oxidation chain to reduce or prevent the start of an oxidoreduction chain, as examples, organic and inorganic peroxide reducers such as glutathione peroxidase and catalase enzymes can be considered.

B) Secondary antioxidants: they are switches that act by blocking at some stage the oxidation chain already initiated by capturing free radicals and by limiting the length of the oxidation chain.

Another way to classify antioxidants is by their chemical structure and biological function, in that sense they can be:

A) Enzymes: within these are glutathione peroxidase, catalase and superoxide dismutase.

B) Non-enzymatic compounds: such as vitamins $\mathrm{C}$ and $\mathrm{E}$, uric acid, bilirubin, among others.

Antioxidants can also be classified according to their enzymatic compounds, which are a type of secondary polyphenols found in most plants, Castro-López and Ortega Régules (9) classify some of the enzymatic compounds, which are the following:

A) Peroxidase: the most important in the mammal is the enzyme glutathione peroxidase, since it is the only one that has been reported to be dependent on selenium, it is also a catalyst for the following reaction, Glutathione $-\mathrm{SH}+\mathrm{H} 2 \mathrm{O} 2-\mathrm{H} 2 \mathrm{O}+\mathrm{S}-\mathrm{S}$ glutathione5.

B) Catalase: it is present in peroxisomes; it works in antioxidant protection and catalyzes the reaction $\mathrm{H} 2 \mathrm{O} 2+\mathrm{H} 2 \mathrm{O} 2-2 \mathrm{H} 2 \mathrm{O}+02$. This enzyme is very important in the elimination of hydrogen peroxide by preventing the catalysis of metals towards $\mathrm{OH}$. However, its low presence in plasma resulted in an increase in its circulating life through structures in the laboratory (10).

C) Superoxide-dismutase: it is the most important, it consists of a tetrameric glycoprotein inducible by corticosteroids. Due to its polymeric structure, isozymes are presented to catalyze the superoxide anion dismutation, possibly the most common radical with consequent inactivation. 
Among the most common antioxidants is sodium ascorbate, which is the sodium salt of vitamin $\mathrm{C}$, they consist of a water-soluble molecule, which interacts with the same oxyradicals, therefore the general objective of the present investigation is to evaluate the effectiveness of tooth whitening after placement of $10 \%$ sodium ascorbate as an antioxidant (11).

\section{MATERIALS AND METHODS}

The population of the present study consists of healthy upper and lower premolar specimens, extracted from patients in an age range of 18 to 22 years, by orthodontic treatments, in the clinic of the Faculty of Dentistry of the Autonomous University of Tamaulipas.

The sample size is 22 bleached premolars, divided into two groups of 11 specimens each. Control group A, bleaching - without sodium ascorbate and experimental Group B, bleaching + sodium ascorbate.

The type of sampling is not probabilistic for convenience.

The procedure was developed in three stages:

\section{Stage 1}

The 22 upper and lower premolars were collected from patients aged 18-22 years extracted for orthodontic reasons (they met inclusion criteria), which were stored in Fermont ${ }^{\circledR}$ deionized water at $37^{\circ} \mathrm{C}$, from their collection until the end of the experiment. With the help of a BioSonic ${ }^{\circledR}$ Model US100R ultrasonic reamer (cavitron), the rest of the tissue was cleaned and removed.

Subsequently, they were randomly selected and placed on a Speedex ${ }^{\circledR}$ silicone base by condensation, divided into two groups of 11 premolars each (Control Group A and Experimental Group B). (Figure 1)

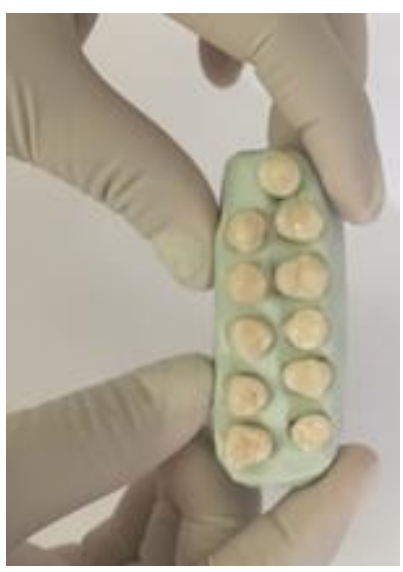




\section{Figure 1: Premolars seeded on Speedex® silicone by condensation}

Once seeded in the condensation silicone, a 0.20-gauge acetate was stamped with the help of a Vacum® thermoforming machine and a number was assigned to each tooth (from one to eleven).

With the help of an electronic Vernier (Mitutoyo ${ }^{\circledR}$ ) the diameter of the spectrophotometer tip was measured, which measured $6 \mathrm{~mm}$. The center of the tooth on the vestibular face was marked on the acetate, placing an adherent paper to be later cut with the help of a scalpel.

Once the center of the vestibular face was discovered, the initial color was taken with the Vita® spectrophotometer, recording the color on a control table before being bleached.

\section{Stage 2}

Following the manufacturer's specifications, the 22 premolars on the vestibular face were bleached and the tooth color was immediately taken again after being bleached with the spectrophotometer and recorded in the data collection format (Figure 2).

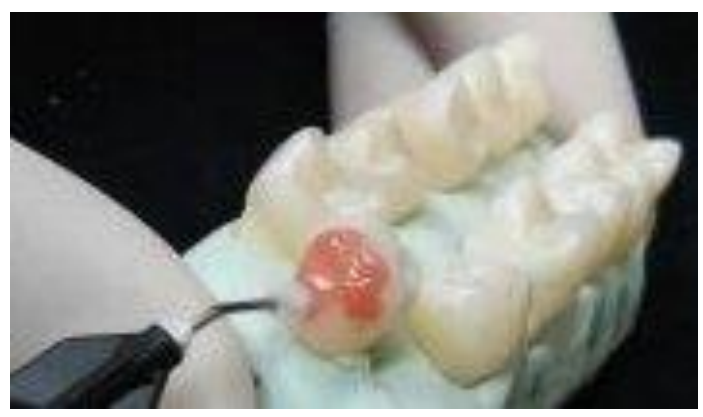

Figure 2: Boost ${ }^{\circledR}$ whitening application on the vestibular face.

The preparation of $10 \%$ sodium ascorbate was performed; With the help of a scale, 10 grams of sodium ascorbate (CEDROSA $®$ ) were weighed and poured onto 100 milliliters of $2 \%$ saline (PISA $®)$ in a Leopolld $®$ sterile clinical dosing vessel where it was mixed.

Experimental group B was immersed in 10\% sodium ascorbate for 10 minutes. Subsequently the color was taken and recorded (Figure 3). 


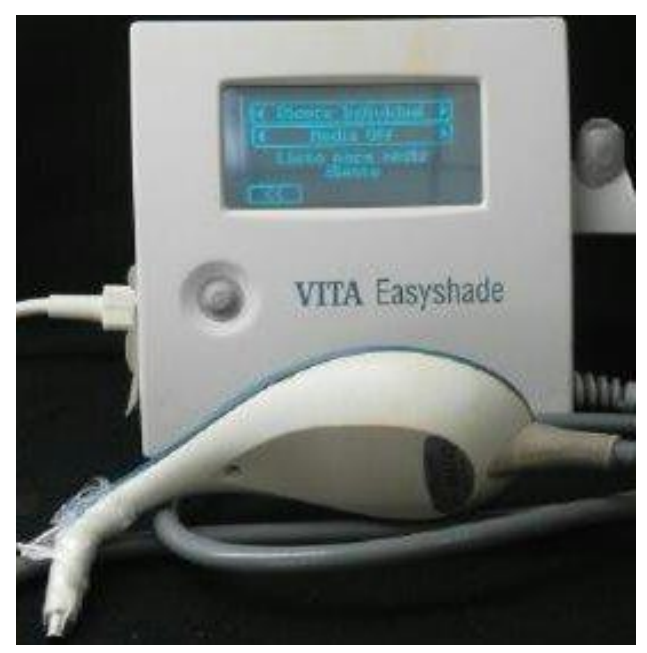

Figure 3: Vita ${ }^{\circledR}$ Easy Shade spectrophotometer.

Control group A and experimental group B were stored in deionized water at a temperature of 37 ${ }^{\circ} \mathrm{C}$ in a Shel-Lab® Model: 1510E incubator for the entire period of time of the experiment. Premolars were removed from the air chamber only for color registration at 3, 7 and 14 days and recorded in the data collection format.

\section{Stage 3}

Once the final color values were obtained, they were classified according to the scale of the Vita ${ }^{\circledR}$ Classic colorimeter, which has 16 values that go from the lightest to the darkest. Thus, obtaining the values that decreased from the first record until the conclusion of the experiment.

\section{STASTICAL ANALYSIS}

The Vita EasyShade results obtained through the spectrophotometer were reported as means and standard deviations; the assumption of normal distribution was tested using the KolmogorovSmirnov test. Moreover, the Anova of two factors was used to evaluate significance effects and subsequently the tukey test was used for post-hoc comparations. All the statiscal analyses were performed using the IBM Statics 23 software.

\section{RESULTS}

According to the VITA CLASSIC color scale, a quantitative scale recoding process was carried out, 1 being the lightest value (B1) and 16 the darkest value (C4). (Table 1). 
Table 1: Value assigned to each color.

\begin{tabular}{|c|c|}
\hline Color & Value \\
\hline $\mathrm{B} 1$ & 1 \\
\hline $\mathrm{A} 1$ & 2 \\
\hline $\mathrm{B} 2$ & 3 \\
\hline $\mathrm{D} 2$ & 4 \\
\hline $\mathrm{A} 2$ & 5 \\
\hline $\mathrm{C} 1$ & 6 \\
\hline $\mathrm{C} 2$ & 7 \\
\hline $\mathrm{D} 4$ & 8 \\
\hline $\mathrm{A} 3$ & 9 \\
\hline $\mathrm{D} 3$ & 10 \\
\hline $\mathrm{B} 3$ & 11 \\
\hline $\mathrm{A} 3.5$ & 12 \\
\hline $\mathrm{B} 4$ & 13 \\
\hline $\mathrm{C} 3$ & 14 \\
\hline $\mathrm{A} 4$ & 15 \\
\hline $\mathrm{C} 4$ & 16 \\
\hline
\end{tabular}

The values obtained were recorded in a table (Table 2) and then analyzed.

Table 2: Color registration.

\begin{tabular}{|c|c|c|c|c|c|c|c|c|}
\hline \multirow{6}{*}{$\begin{array}{l}\text { In the } \\
\text { obtained } \\
\text { multiple }\end{array}$} & Groups & Value & $\begin{array}{l}\text { Initial } \\
\text { color }\end{array}$ & $\begin{array}{c}\text { Inmediate } \\
\text { to } \\
\text { Treatment }\end{array}$ & $\begin{array}{c}3 \\
\text { day } \\
\text { color }\end{array}$ & $\begin{array}{c}7 \\
\text { day } \\
\text { color }\end{array}$ & $\begin{array}{c}14 \\
\text { day } \\
\text { color }\end{array}$ & \multirow[t]{3}{*}{$p$ value } \\
\hline & \multirow{2}{*}{$\begin{array}{l}\text { A Group } \\
\text { Control }\end{array}$} & Mean & 8.4 & 8.5 & 3.1 & 2.9 & 2.5 & \\
\hline & & $\begin{array}{l}\text { Standard } \\
\text { deviation }\end{array}$ & 3.0 & 2.9 & 0.7 & 0.3 & 0.8 & \\
\hline & \multirow{2}{*}{$\begin{array}{c}\text { B Group } \\
\text { Experimental }\end{array}$} & Mean & 8.5 & 8.7 & 3.4 & 2.8 & 2.5 & \multirow[t]{2}{*}{$<0.0001$} \\
\hline & & $\begin{array}{l}\text { Standard } \\
\text { deviation }\end{array}$ & 3.5 & 3.6 & 0.8 & 0.4 & 0.7 & \\
\hline & \multicolumn{2}{|c|}{$p$ value } & 0.837 & 0.733 & 0.328 & 0.544 & 0.811 & \\
\hline
\end{tabular}

independent comparisons with the Bonferroni adjustment, no statistically significant differences were observed in any of the evaluated color stages between the study groups (Figure 4). 


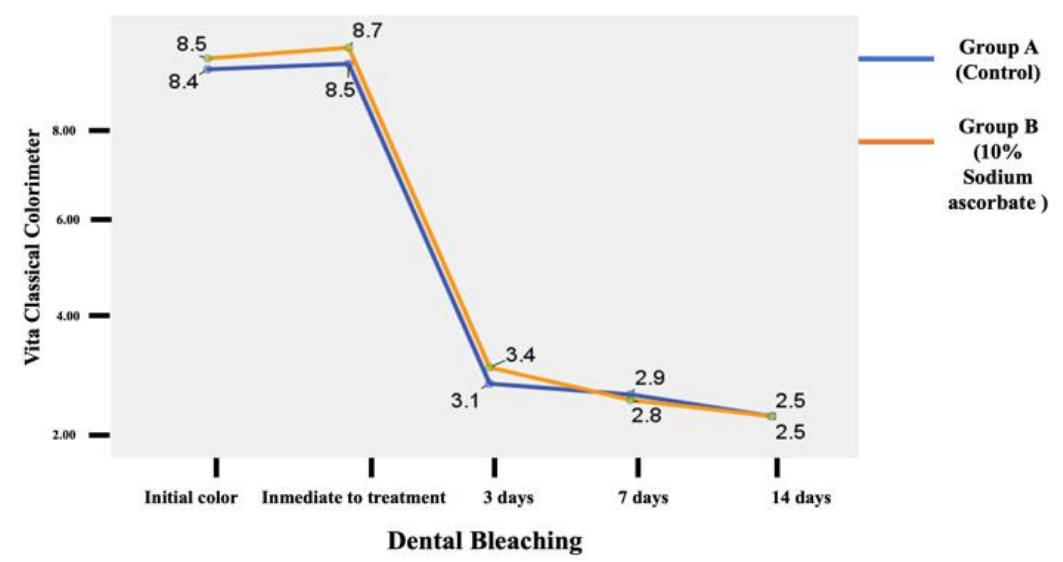

\section{Figure 4: Comparison between both groups from the start of treatment to 14 days. Parallel view.}

\section{DISCUSSION}

The requirement of whiter teeth has become one of the major concerns in dental practice, given that the discoloration of one or a group of teeth negatively interferes with the harmony of the smile and has an impact on the psychological well-being of the patient.

Various studies have been carried out, which argue that an attractive smile in our society is considered a necessary quality in social interactions, as well as in job interviews. For this reason it is very important for dental staff, to have the knowledge of the different bleaching agents based on the application of highly oxidizing substances and techniques such as veneers, crowns, resin restorations and teeth whitening that can be applied to solve this need; since teeth whitening is one of the main treatments requested today.

There are currently no studies where the effectiveness of tooth whitening is verified after the placement of $10 \%$ sodium ascorbate; the purpose of this study is to demonstrate that after the application of sodium ascorbate, statistically significant values similar to the control group will be obtained.

Although, no evidence was found in the literature of any clinical trial evaluating the use of antioxidants to measure whether or not it affects the effectiveness of tooth whitening.

22 bovine incisors were used, where the vestibular faces were planned, being divided into 4 experimental groups according to each antioxidant agent, with two subgroups each, varying the application time from 1 to 10 minutes, all subjected to the same bleaching (peroxide hydrogen) where the control group was restored; and the other groups were treated with the respective 


\section{International Journal of Engineering Technology and Scientific Innovation}

ISSN: 2456-1851

Volume: 05, Issue: 01 "January-February 2020"

antioxidants prior to the restorative procedure, an adhesive system (All Bond® 3 ) being used and as a composite resin (Filtek® Z-350). Therefore, it was shown that teeth treated with antioxidants favored adhesion (12).

Some studies have revealed that the use of ascorbate and other antioxidants before the adhesion process reverses the reduction of adhesion forces induced by tooth whitening, this because it neutralizes the oxidation effect of the clearing agent and increases the strength of enamel adhesion (13).

In relation to the application time of sodium ascorbate Türkün (11) carried out a pilot study in which $10 \%$ of hydrogen was used for 10 minutes, 1,2,4 and 8 hours to determine the period of application, stating that the application for more than 2 hours does not significantly increase the value of the adhesion force, without offering any additional data, while the one exposed for ten minutes was effective.

However, Lai (14) used a 10\% solution for 3 hours and Kimyai (13) used a 10\% solution and $20 \%$ hydrogel for three hours obtaining favorable results, since these application times were able to reverse the adhesion force. Before being taxed with phosphoric acid, the treated teeth were immersed in distilled water for 10 minutes to dissolve the sodium ascorbate crystals that were deposited on the adhesion surface, thus achieving a reversal of the bond strength commitment.

The results of the present investigation regarding the use of teeth whitening (38\% hydrogen peroxide) after the application of an antioxidant (10\% sodium ascorbate), does not present statistically significant changes, which indicates that the use of an antioxidant after the application of hydrogen peroxide (38\%) does not affect the effectiveness of teeth whitening. Therefore, it is shown that sodium ascorbate (10\%) in previous studies is of greater benefit in dental practice offering better results.

\section{CONCLUSIONS}

With the limitations of the study and under the methodology used we reach the following conclusions:

1. The clearance performance with $38 \%$ hydrogen peroxide in both the control group and the experimental group; showed a significant difference three days after application.

2. Sodium ascorbate $10 \%$ as an antioxidant in the treatment of teeth whitening, does not affect the effectiveness of hydrogen peroxide $(\mathrm{H} 2 \mathrm{O} 2)$ at $38 \%$ when evaluated immediately after application, and in the same way when observing the same performance at three, seven and fourteen days later. 
International Journal of Engineering Technology and Scientific Innovation

ISSN: 2456-1851

Volume: 05, Issue: 01 "January-February 2020"

3. No statistically significant change was observed between the control group and the experimental group, both showed the same effectiveness by having decreased two color values each after the application of the lightening treatment.

\section{REFERENCES}

1. Bittencourt ME, Trentin MS, Linden MS, De Oliveira Lima Arsati YB, França FM. Influence of in situ post bleaching times on shear bond strenght of resin based composite restoration, JADA 2010; 41: 300-6.

2. Gómez de Ferraris ME y Campos Muñoz A. Histología y embriología bucodental. 2 ed. Madrid, España: Médica Panamericana, 2002: 271-315.

3. Haywood V. The food and drug administration and it's influence on home bleaching Curr Opin Cosmet Dent 1993; 1:. 12-18.

4. Haywood V. Current status of night guard vital bleaching, Compendium of Continuing Education in Dentistry 2000; 28: 10-7.

5. Marshall MB, Gragg PP, Packman EW, Wright PB. Hydrogen peroxide descomposition in the oral cavity, Am J Dent 2001; 14: 39-45.

6. Martín C, Martín G, García A, Fernández T, Hernández E. Potenciales aplicaciones de Moringa Oleifera. Una revisión crítica. Pastos y Forrajes 2013; 36(2): 137-49.

7. Zamora J. Antioxidantes: Micronutrientes en la lucha por la salud, Rev Chil Nutr 2007; 34:1-15.

8. Nieto Alcaide S., Martínez Vázquez de Parga C M. Determinación del color en odontología, Rev. Int Prot Estomatológica 2000; 2(5): 370-83.

9. Castro - Lopez LR, Ortega-Regules AE. Modificaciones enzimáticas de compuestos fenólicos, Temas Selectos de Ingeniería de Alimentos 2015; 9: 5-14.

10. Mortazavi V, Fathi MH, Ataei E. The effect of $15 \%$ Carbamide Peroxide Bleaching on the shear bond strength of composite to enamel., Shiraz Univ Dent 2009; 9(24): 24-30.

11. Türkün M, Celik EU, Kaya AD, Arici, M. Can the hydrogel form of sodium ascorbate be used to reverse compromised bond strength after bleaching?, J Adhes Dent 2009; 11: 3540.

12. Rodívan Braz CEP, Ribeiro IAM, Guenes Gymenna MT, Dantas Darlene, CRE, Montes Marcos AJR, Feitosa Diala A. Influence of antioxidants on strees of bonding agents in recently whitened teeth, Acta Odontol Lationoam 2011; 24(3): 252-7.

13. Kimyai S, Valizadeh $\mathrm{H}$. The effect of hydrogel and solution of sodium ascorbate on bond strength in bleached enamel, Oper Dent 2006; 31: 496-9.

14. Lai S C N., Tay Fr., Cheung G S P, Mak Y F, Carvalho R M, Wei S H Y, Ty ano M, Osorio R P D H. Reversal of Compromised Bonding in bleached enamel, Reversal of Compromised Bonding in bleached enamel 2002; 81(7): 477-81. 